\title{
KDR (VEGFR2) Genetic Variants and Serum Levels in Patients with Rheumatoid Arthritis
}

\author{
Agnieszka Paradowska-Gorycka 1,*iD, Barbara Stypinska ${ }^{1}$, Andrzej Pawlik ${ }^{2} \mathbb{D}$, \\ Damian Malinowski ${ }^{3}$, Katarzyna Romanowska-Prochnicka ${ }^{4,5}$, Malgorzata Manczak ${ }^{6}$ and \\ Marzena Olesinska ${ }^{4}$ \\ 1 Department of Molecular Biology, National Institute of Geriatrics, Rheumatology and Rehabilitation, \\ Spartańska 1, 02-637 Warsaw, Poland \\ 2 Department of Physiology, Pomeranian Medical University, 70-111 Szczecin, Poland \\ 3 Department of Pharmacology, Pomeranian Medical University, 70-111 Szczecin, Poland \\ 4 Department of Connective Tissue Diseases, National Institute of Geriatrics, \\ Rheumatology and Rehabilitation, 02-637 Warsaw, Poland \\ 5 Department of Pathophysiology, Warsaw Medical University, 02-637 Warsaw, Poland \\ 6 Department of Gerontology and Health Promotion, National Institute of Geriatrics, \\ Rheumatology and Rehabilitation, 02-637 Warsaw, Poland \\ * Correspondence: agnieszka.paradowska-gorycka@spartanska.pl; Tel.: +48-228-445-726
}

Received: 23 July 2019; Accepted: 7 August 2019; Published: 9 August 2019

\begin{abstract}
We investigated kinase insert domain-containing receptor (KDR) polymorphisms and protein levels in relation to susceptibility to and severity of Rheumatoid Arthritis (RA). 641 RA patients and 340 controls (HC) were examined for the rs1870377 KDR variant by the polymerase chain reaction (PCR)-restriction fragment length polymorphism (RFLP) method and for rs2305948 and rs2071559 KDR single nucleotide polymorphisms (SNPs) by TaqMan SNP genotyping assay. KDR serum levels were determined by enzyme-linked immunosorbent assay (ELISA). The rs1870377 KDR variant has shown association with $\mathrm{RA}$ under the codominant $(p=0.02, \mathrm{OR}=1.76,95 \% \mathrm{CI}=1.09-2.85$ ) and recessive models $(p=0.019, \mathrm{OR}=1.53,95 \% \mathrm{CI}=1.07-2.20)$. KDR rs2305948 was associated with RA under the dominant model $(p=0.005, \mathrm{OR}=1.38,95 \% \mathrm{CI}=1.10-1.73)$. Under the codominant model, the frequency of the rs2071559 TC and GG genotypes were lower in RA patients than in controls $(p<0.001, \mathrm{OR}=0.51,95 \% \mathrm{CI}=0.37-0.69$, and $p=0.002, \mathrm{OR}=0.57,95 \% \mathrm{CI}=0.39-0.81)$. KDR rs2071559 $\mathrm{T}$ and $\mathrm{rs} 2305948 \mathrm{~A}$ alleles were associated with $\mathrm{RA}(p=0.001, \mathrm{OR}=0.60,95 \% \mathrm{CI}=0.45-0.81$ and $p=0.008, \mathrm{OR}=1.71, \mathrm{CI}=1.15-2.54)$. KDR rs2305948SNP was associated with Disease Activity Score (DAS)-28 score $(p<0.001)$, Visual Analog Scale (VAS) score $(p<0.001)$, number of swollen joints $(p<0.001)$, mean value of CRP $(p<0.001)$. A higher KDR serum level was found in RA patients than in $\mathrm{HC}(8018 \mathrm{pg} / \mathrm{mL}$ versus $7381 \mathrm{pg} / \mathrm{mL}, p=0.002)$. Present results shed light on the role of KDR genetic variants in the severity of RA.
\end{abstract}

Keywords: angiogenesis; inflammation; gene polymorphisms; KDR; rheumatoid arthritis; protein level

\section{Introduction}

Rheumatoid arthritis (RA) is not only autoimmune disease, but it is also a member of the "angiogenic family of diseases" due to active tissue neovascularization [1,2]. Although the molecular mechanisms promoting neovascularization/angiogenesis in patients with RA have not been clearly identified, it is accepted that this process may lead to immune activation as well as the progression of synovitis [3-5]. Synovial angiogenesis is clearly a feature of both early and late stages of RA, with vascular endothelial growth factor (VEGF) playing a pivotal role not only in angiogenesis but also 
in inflammation [6-8]. VEGF acts through interaction with the one or both high-affinity tyrosine kinase receptors, VEGF receptor-1(VEGFR-1) and VEGF receptor-2 (VEGFR-2) [9-11]. VEGFR2, also known as fetal liver kinase-1 (Flk-1) in mice and kinase insert domain-containing receptor (KDR) in humans, is a major mediator of angiogenic, mitogenic, and vascular permeability activity [12-14]. In addition, KDR expression increased in response to hypoxia, which is a key inducer of VEGF gene transcription [5]. An increased VEGF/KDR signaling not only enhanced angiogenesis but also play a key role in atherosclerosis as well as a chronic inflammation $[15,16]$.

In response to pro-inflammatory cytokines, the VEGF/KDR system expression, in serum as well as the synovial fluid of patients with RA, is upregulated and has shown association with disease severity and activity [11,17-22]. Thus, mechanisms involved in VEGF/KDR system control may be critical in autoimmunity and in RA development and/or course. In our earlier study, we have shown that VEGF single nucleotide polymorphisms (SNPs), as well as serum VEGF levels, may be associated with the onset of RA [23]. In order to better define the role of genetic factors essential for the development of RA and its clinical manifestation, it is necessary to recognize an individual's likely developing rheumatoid arthritis. Studies on SNPs that affect the risk of developing rheumatoid arthritis are numerous. However, there are few reports on how gene polymorphisms may modulate the severity of RA. Some previous studies have shown that LRP5 A1330V, LRP5 V667 M, RAD51B rs911263, TLR10 I473T, IL-6 rs4453032 SNPs were associated with erosion in RA patients [24-27]; LRP5 V667 M, NLRP3 rs10754558 and CARD8 rs2043211 polymorphisms were associated with Health Assessment Questionnaire (HAQ) scores [24,28]; and FLT-1 rs7324510 and AFF3 rs11676922 SNPs were associated with VAS score, DAS-28 score, and ExRA presence [29,30].

In this study, we carry out a candidate gene study of the correlation between KDR and the susceptibility to and severity of RA. We selected three functional SNPs located in the KDR gene and analyzed their association with RA in the Polish population. In a subgroup of 272 patients with RA, we also determined the KDR serum levels, which were next correlated with the severity of RA, RA phenotype, and KDR genotypes. Moreover, we also examined whether the KDR gene SNPs and serum KDR levels are related to the development of cardiovascular disease (CVD) in our RA patients.

\section{Results}

\subsection{Characteristics of the Study Population}

Our study population included 641 patients with RA and 340 healthy subjects as a control group (217 females and 123 males aged between 18 and 63 years). Demographic and clinical characteristics of our RA patients, collected at the time blood sampling, is presented in Table 1. Among all RA patients, 69\% were RF positive, and 80\% had the Anti-Citrullinated Peptide Antibody (ACPA). Table 2 was shown characteristics of RA patients with and without cardiovascular events (CVD). The symptoms of CAD was found in $13 \%$ of patients, myocarditis in 3\% of patients, and hypertension in $36 \%$ of patients; all this evidence was classified as CVD. In the present study, we observed that RA patients with CVD were older (62 versus 53 years; $p<0.001$ ) and had a higher activity of disease than RA patients without CVD. However, after Bonferroni correction for multiple testing, the parameters such as the mean value of ESR and CRP, HAQ score, and creatinine levels did not show significant differences between RA patients with CVD and without CVD.

Table 1. Demographic and clinical characteristics of patients with Rheumatoid Arthritis (RA).

\begin{tabular}{ccc}
\hline \multirow{2}{*}{ Characteristics } & \multicolumn{2}{c}{ RA Patients } \\
\cline { 2 - 3 } & $\mathbf{N}$ & Mediana (IQR) \\
\hline Age (years) & 616 & $56.2 \pm 12.5(22-89)$ \\
\hline Disease duration (years) & 524 & $11.2 \pm 8.7(0-48)$ \\
\hline Larsen & 567 & $3.0 \pm 1.0(0-5)$ \\
\hline
\end{tabular}


Table 1. Cont.

\begin{tabular}{ccc}
\hline \multirow{2}{*}{ Characteristics } & \multicolumn{2}{c}{ RA Patients } \\
\cline { 2 - 3 } & $\mathbf{N}$ & Mediana (IQR) \\
\hline Number of swollen joints & 340 & $4.6 \pm 4.9(0-26)$ \\
\hline Number of tender joints & 338 & $8.0 \pm 6.1(0-28)$ \\
\hline ESR $(\mathrm{mm} / \mathrm{h})$ & 565 & $35.0 \pm 24.5(0-164)$ \\
\hline CRP $(\mathrm{mg} / \mathrm{L})$ & 345 & $22.5 \pm 24.2(0-144)$ \\
\hline Hemoglobin $(\mathrm{g} / \mathrm{dL})$ & 345 & $12.5 \pm 1.5(8.1-16.5)$ \\
\hline VAS $(\mathrm{mm})$ & 331 & $52.3 \pm 23.9(0-100)$ \\
\hline DAS $28-\mathrm{CRP}$ & 334 & $4.89 \pm 1.40(0.97-7.95)$ \\
\hline HAQ & 288 & $1.47 \pm 0.72(0-3.125)$ \\
\hline PLT $\left(\times 10^{3} / \mathrm{mm}^{3}\right)$ & 345 & $321.17 \pm 106.10(0-948)$ \\
\hline Creatinine & 344 & $0.73 \pm 0.24(0-2.60)$ \\
\hline RF presence & $\mathbf{N}$ & $386(69 \%)$ \\
\hline anti-CCP presence & 561 & $280(80 \%)$ \\
\hline Coronary artery disease CAD & 348 & $46(13 \%)$ \\
\hline Hypertension $(\mathrm{HNT})$ & 343 & $123(36 \%)$ \\
\hline Myocarditis $(\mathrm{MI})$ & 344 & $12(3.5 \%)$ \\
\hline
\end{tabular}

$\mathrm{N}$-number of patients with clinical information's; $\mathrm{n}$-number of patients with positive clinical manifestation; DAS-28-disease activity score for 28 joints, VAS - visual analogue scale (range 0-100), HAQ-Health Assessment Questionnaires (range 0-3), CRP-C-reactive protein, ESR-erythrocyte sedimentation ratio, PLT-platelet, $\mathrm{RF}-$ rheumatoid factor, anti-CCP—anti-CCP antibodies. IQR-interquartile range;

Table 2. Clinical characteristics of patients with cardiovascular diseases.

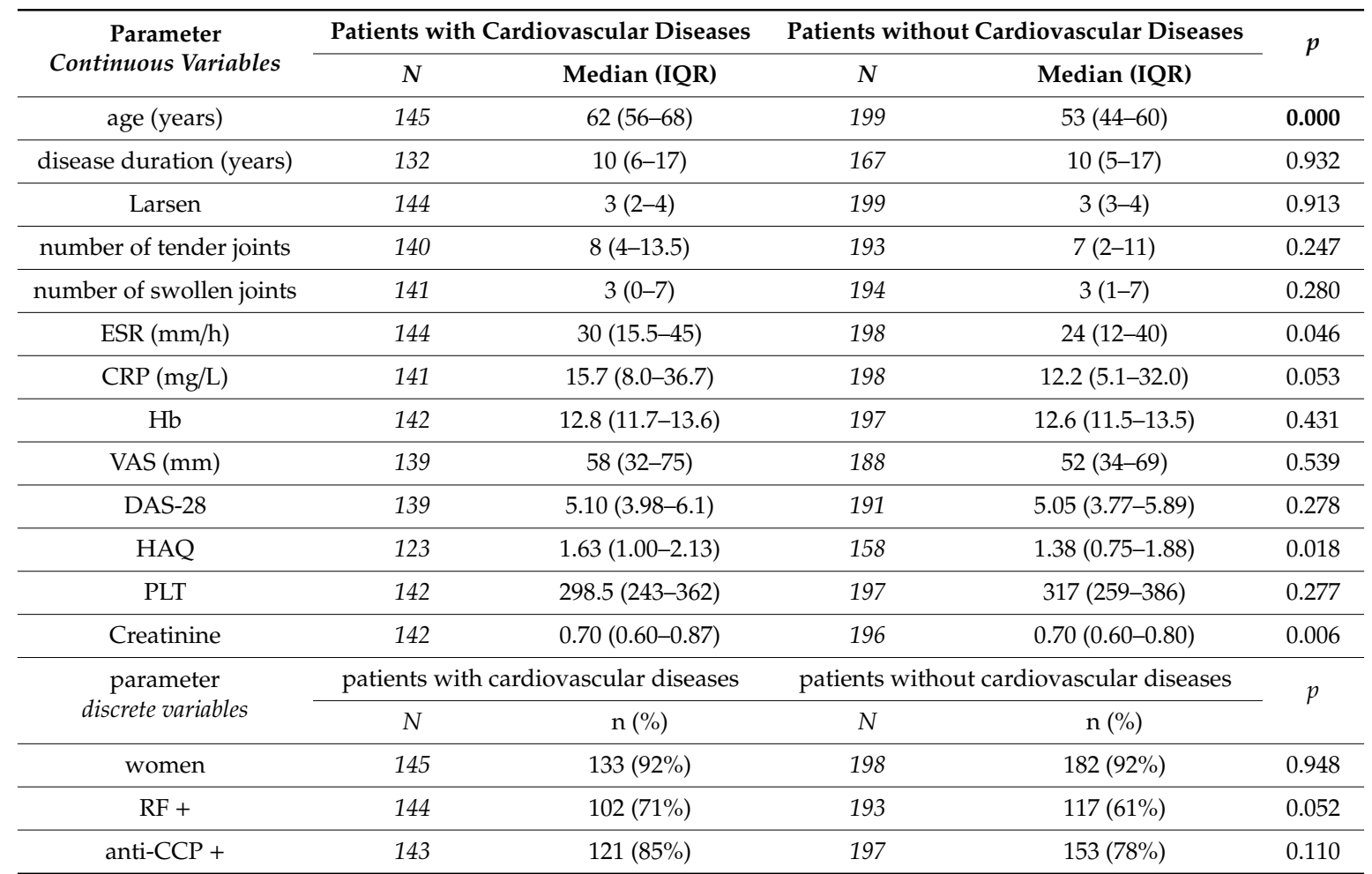

$\mathrm{N}$-number of patients with clinical information's; $\mathrm{n}$-number of patients with positive clinical manifestation; $p<0.003$ was considered significant (according to Bonferroni correction). 
2.2. Information about KDR Gene SNPS as Well as Distribution of the KDR Genetic Variants in RA Patients and Controls

Two nonsynonymous coding SNPs at position rs2305948 (V297I) and rs1870377 (H472Q) are located in the extracellular fourth and fifth immunoglobulin-like domains, which are important for binding the VEGF to KDR [31,32]. KDR rs2071559 (-604T/C) SNP is located in the 5' untranslated region (5'-UTR) of the gene, and it may affect the KDR transcription. This genetic variant may probably change the structure of the binding site for the transcriptional factor E2F (involving in cell cycle regulation) in the KDR gene promoter region $[31,33]$.

The minor allele frequency (MAF) of the two chosen SNPs, rs2305948 and rs2071559 in our cohorts were similar to those in the western European ancestry and Utah residents of northern (HapMap database; Table S1 in Supplementary files). Furthermore, the KDR minor rs1870377 T allele frequency was higher in Polish RA patients (32\%) as well as controls (27\%) than in other European populations (21\%). Using the selected sample size of 641 RA patients and 340 healthy controls at the significance level of 0.05 , the power of our study was $96 \%$ for rs $1870377,87 \%$ for rs 2305948 and $98 \%$ for rs 2071559 .

Next, we checked an association between KDR genetic variants and susceptibility to RA. The distributions of the KDR rs1870377, rs2071559 and rs2305948genotypes among RA patients and healthy subjects, were presented in Table 3. Three genetic models such as codominant, dominant and recessive we used to assess the possible association between KDR SNPs and RA risk.

We observed a significant difference in genotype frequency of KDR rs1870377 and rs2071559 polymorphisms between RA patients and control groups. The frequency of the rs1870377TT genotype was higher in RA patients compared with controls under the codominant and recessive model $(p=0.02$ and $p=0.019$, respectively). Frequency of the rs2071559TC and rs2071559CC genotypes were significantly lower in RA patients compared to the healthy subjects $(p<0.001$ and $p=0.002$, respectively). Moreover, under the dominant model, the frequency of the TC + CC genotype was also lower in RA patients than in controls $(p<0.001)$. In the case of the rs2305948 KDR variant, we found that under the dominant model the frequency of the GA + AA genotype was significantly higher in RA patients than in healthy subjects $(p=0.005)$.

Our analysis revealed that KDR gene rs2305948 A allele was associated with significantly increased risk of RA ( $p=0.008$ ) than the rs $2305948 \mathrm{G}$ allele in the Polish population. Furthermore, KDR gene rs2071559 C allele was more frequently observed in healthy subjects than in RA patients $(p=0.001)$.

Table 3. Genetic effects of individual Single Nucleotide Polymorphisms (SNPs) in the kinase insert domain-containing receptor (KDR) gene on RA risk.

\begin{tabular}{|c|c|c|c|c|c|}
\hline KDR SNP & Genotype & RA n (\%) & Controls n (\%) & Adjusted OR (95\% CI) & $p$-Value \\
\hline \multicolumn{6}{|c|}{ rs1870377A/T (+1416A/T) } \\
\hline \multirow{3}{*}{ Codominant } & AA & $291(48 \%)$ & $167(53 \%)$ & 1 & - \\
\hline & AT & $239(40 \%)$ & $120(38 \%)$ & $0.78(0.55-1.09)$ & 0.139 \\
\hline & $\mathrm{TT}$ & $72(12 \%)$ & $26(8 \%)$ & $1.76(1.09-2.85)$ & 0.020 \\
\hline \multirow{2}{*}{ Dominant } & AA & $291(48 \%)$ & $167(53 \%)$ & 1 & \\
\hline & $\mathrm{AT}+\mathrm{TT}$ & $311(52 \%)$ & $146(47 \%)$ & $1.12(0.91-1.39)$ & 0.286 \\
\hline \multirow{2}{*}{ Recessive } & $\mathrm{AA}+\mathrm{AT}$ & $530(88 \%)$ & $287(92 \%)$ & 1 & \\
\hline & $\mathrm{TT}$ & $72(12 \%)$ & $26(8 \%)$ & $1.53(1.07-2.20)$ & 0.019 \\
\hline \multirow[t]{2}{*}{ Allele } & $\mathrm{A}$ & $821(68 \%)$ & $454(73 \%)$ & 1 & - \\
\hline & $\mathrm{T}$ & $383(32 \%)$ & $172(27 \%)$ & $1.38(1.00-1.92)$ & 0.053 \\
\hline
\end{tabular}


Table 3. Cont.

\begin{tabular}{|c|c|c|c|c|c|}
\hline KDR SNP & Genotype & RA n (\%) & Controls n (\%) & Adjusted OR (95\% CI) & $p$-Value \\
\hline \multicolumn{6}{|c|}{ rs2305948 G/A (+889G/A) } \\
\hline \multirow{3}{*}{ Codominant } & GG & $409(64 \%)$ & $245(72 \%)$ & 1 & - \\
\hline & GA & $224(35 \%)$ & $94(28 \%)$ & $0.72(0.21-2.55)$ & 0.614 \\
\hline & AA & $8(1 \%)$ & $1(0 \%)$ & $3.56(0.30-42.35)$ & 0.314 \\
\hline \multirow{2}{*}{ Dominant } & GG & $409(64 \%)$ & $245(72 \%)$ & 1 & \\
\hline & $\mathrm{GA}+\mathrm{AA}$ & $232(36 \%)$ & $95(28 \%)$ & $1.38(1.10-1.73)$ & 0.005 \\
\hline \multirow{2}{*}{ Recessive } & GG + GA & $633(99 \%)$ & $339(100 \%)$ & 1 & \\
\hline & AA & $8(1 \%)$ & $1(0 \%)$ & $2.73(0.43-17.37)$ & 0.287 \\
\hline \multirow[t]{2}{*}{ Alleles } & G & $1042(81 \%)$ & $584(86 \%)$ & 1 & - \\
\hline & $\mathrm{A}$ & $240(19 \%)$ & $96(14 \%)$ & $1.71(1.15-2.54)$ & 0.008 \\
\hline \multicolumn{6}{|c|}{ rs2071559 T/C (-604 T/C) } \\
\hline \multirow{3}{*}{ Codominant } & TT & $163(26 \%)$ & $17(5 \%)$ & 1 & - \\
\hline & $\mathrm{TC}$ & $335(52 \%)$ & $239(70 \%)$ & $0.51(0.37-0.69)$ & 0.000 \\
\hline & $\mathrm{CC}$ & $141(22 \%)$ & $84(25 \%)$ & $0.57(0.39-0.81)$ & 0.002 \\
\hline \multirow{2}{*}{ Dominant } & TT & $163(26 \%)$ & $17(5 \%)$ & 1 & \\
\hline & $\mathrm{TC}+\mathrm{CC}$ & $476(74 \%)$ & $323(95 \%)$ & $0.39(0.27-0.55)$ & 0.000 \\
\hline \multirow{2}{*}{ Recessive } & $\mathrm{TT}+\mathrm{TC}$ & 498 (78\%) & $256(75 \%)$ & 1 & \\
\hline & $\mathrm{CC}$ & $141(22 \%)$ & $84(25 \%)$ & $0.90(0.71-1.14)$ & 0.360 \\
\hline \multirow[t]{2}{*}{ Alleles } & $\mathrm{T}$ & $661(52 \%)$ & $273(40 \%)$ & 1 & - \\
\hline & $\mathrm{C}$ & $617(48 \%)$ & $407(60 \%)$ & $0.60(0.45-0.81)$ & 0.001 \\
\hline
\end{tabular}

\subsection{Genetic Effects of the KDR Haplotypes on the RA risk}

The linkage disequilibrium (LD) map of the KDR rs1870377, rs2305948, and rs2071559 polymorphisms was generated using the SHEsis program. The analysis results revealed weak LD between examined KDR gene polymorphism, as the $\mathrm{r} 2$ value between all of them is considerably low Figure 1.

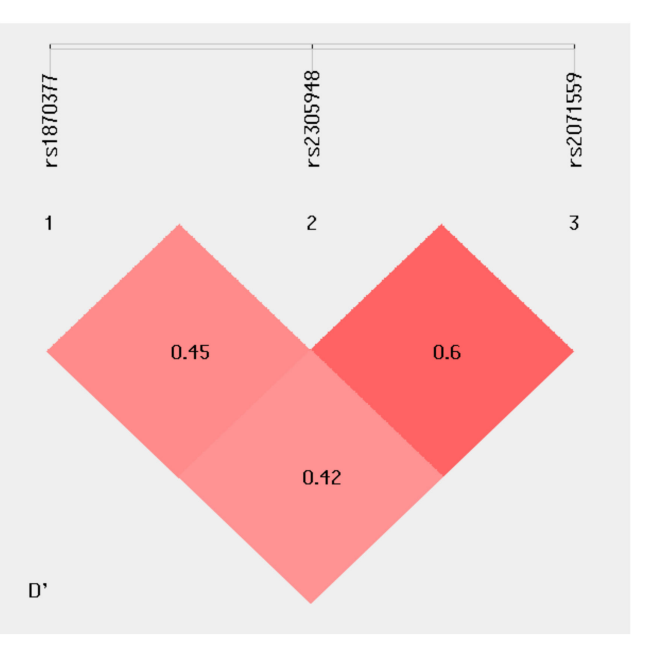

a) D' value

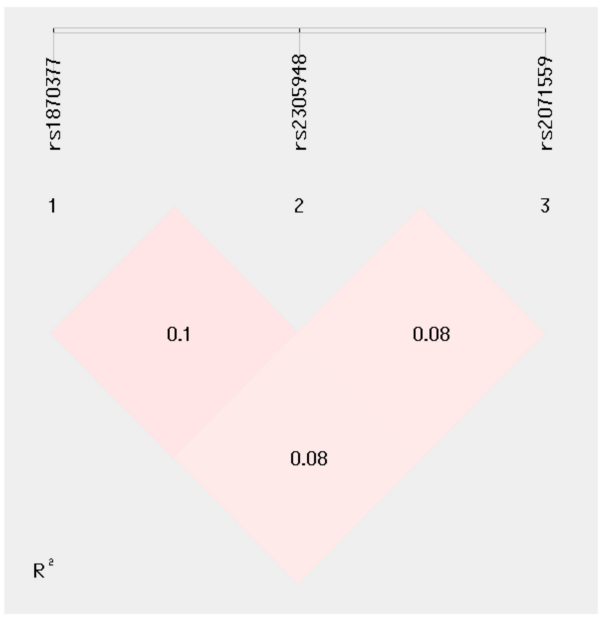

b) $\mathrm{r}^{2}$ value

Figure 1. (a), D' value; (b), $\mathrm{r}^{2}$ value. Linkage disequilibrium (LD) map of the KDR gene polymorphisms. The map illustrates the pairwise LD between KDR SNPs based on $\mathrm{D}^{\prime}$ and $\mathrm{r}^{2}$ values. Values approaching zero indicate the absence of LD, and those approaching 100 indicate complete LD. 
Next, we investigated whether haplotypes created by the examined polymorphisms located in the KDR gene may have an impact on the RA risk in our population. Six major KDR haplotypes with frequency $>0.03 \%$, were found in patients with RA as well as in controls (Table 4). The most common haplotypes identified in our Polish population were rs1870377A/rs2305948G/rs2071559C, which were estimated with frequencies of $37 \%$ in RA patients and $49.8 \%$ in healthy subjects. This association is translated into a protective effect $(\mathrm{OR}=0.601, \mathrm{CI}=0.494-0.731 ; p<0.001)$. Another often observed haplotype in our population was rs1870377A/rs2305948G/rs2071559T. This AGT haplotype was observed in $24 \%$ of RA patients and $17 \%$ of healthy subjects, and it may be associated with risk of $\mathrm{RA}(\mathrm{OR}=1.506, \mathrm{CI}=1.176-1.927 ; p=0.001)$. For the other haplotypes, we found no differences in haplotype distribution between patients with RA and controls.

Table 4. KDR haplotypes in rheumatoid arthritis patients and controls.

\begin{tabular}{|c|c|c|c|c|}
\hline $\begin{array}{c}\text { Haplotype } \\
\text { 1416A/T } \\
889 \mathrm{G} / \mathrm{A} \\
604 \mathrm{~T} / \mathrm{C}\end{array}$ & $\underset{2 n=1200 \text { (freq) }}{\text { RA }}$ & $\begin{array}{c}\text { Control } \\
2 n=622(\text { freq) }\end{array}$ & $p$-Value & Odds Ratio (95\%CI) \\
\hline AGC & $449(0.374)$ & $310(0.498)$ & $<0.001$ & $0.601(0.494-0.731)$ \\
\hline TAT & $116(0.096)$ & $47(0.075)$ & 0.141 & $1.309(0.919-1.864)$ \\
\hline TGT & $154(0.128)$ & $67(0.107)$ & 0.225 & $1.219(0.899-1.654)$ \\
\hline AGT & $286(0.238)$ & $107(0.172)$ & 0.001 & $1.506(1.176-1.927)$ \\
\hline TGC & $85(0.07)$ & 47 (0.075) & 0.704 & $0.932(0.644-1.35)$ \\
\hline AAT & $66(0.055)$ & $23(0.036)$ & 0.108 & $1.515(0.933-2.461)$ \\
\hline
\end{tabular}

\subsection{Association between KDR rs2305948 Polymorphism and Clinical Phenotype of Rheumatoid Arthritis}

Because KDR rs1870377, rs2305948, and rs2071559-genetic variants showed association in the pooled analysis of Polish subjects, and because of our hypothesis that KDR may be a good candidate gene to play a part in RA inflammatory processes, we decided to carry on analysis whether KDR SNPs may have an impact on RA phenotype. Our data showed that only the KDR rs2305948 polymorphism was significantly associated with the RA phenotype. As shown in Table 5, a detailed genotype-phenotype comparison was conducted among RA patients in relation to demographic, clinical, as well as biochemical parameters. After Bonferroni correction, our analyses indicate significant correlation of the KDR rs2305948GG variant with the number of swollen joints $(p<0.001)$, CRP $(p<0.001)$, VAS score $(p<0.001)$, and DAS-28 score $(p<0.001)$. Our analysis did not show significant relationship between KDR rs2305948+889 GG variant and HAQ score $(p=0.027)$, Larsen score $(p=0.03)$, ESR $(p=0.006)$, as well as creatinine level $(p=0.027)$.

The carriers of this KDR rs2305948GG genotype had mostly higher laboratory parameters compared to RA patients with the KDR rs2305948A allele. In contrast, we also observed that the number of RA women with KDR rs2305948A allele was higher than the number of RA women with $K D R$ rs2305948GG variant $(p<0.001)$. The influence of KDR rs1870377 and rs2071559 polymorphisms on clinical symptoms of RA showed a significant correlation with RF presence and with the number of women, respectively. RF was more frequently observed in RA patients with the KDR rs1870377T allele than in RA patients with the KDR rs1870377AA genotype-this association was not significant after Bonferroni correction ( $p=0.03$, Table S2 in Supplementary files). Furthermore, the number of RA women with the KDR rs2071559C allele was higher than the number of RA women with the $K D R$ rs2071559TT genotype-this association was not significant after Bonferroni correction $(p<0.05$, Table S3 in Supplementary files). 
Table 5. Association between genotypes of KDR $+889 \mathrm{G} / \mathrm{A}$ and clinical characteristics among RA patients.

\begin{tabular}{|c|c|c|c|c|c|}
\hline \multirow{2}{*}{ Parameter } & \multicolumn{2}{|c|}{ GG } & \multicolumn{2}{|c|}{$\mathrm{GA}+\mathrm{AA}$} & \multirow{2}{*}{$p^{*}$} \\
\hline & $N$ & Median (IQR) & $N$ & Median (IQR) & \\
\hline Age (years) & 631 & $50(32-59)$ & 23 & $52(33-62)$ & 0.737 \\
\hline Disease duration (years) & 322 & $10(4-16)$ & 202 & $9(5-15)$ & 0.588 \\
\hline Larsen & 355 & $3(3-3)$ & 211 & $3(3-4)$ & 0.030 \\
\hline Number of tender joints & 175 & $8(4-12)$ & 163 & $6(2-11)$ & 0.062 \\
\hline Number of swollen joints & 176 & $4(2-9)$ & 164 & $2(0-6)$ & 0.000 \\
\hline $\operatorname{ESR}(\mathrm{mm} / \mathrm{h})$ & 355 & $31(19-51)$ & 209 & $28(15-40)$ & 0.006 \\
\hline CRP (mg/L) & 177 & $17(8-40)$ & 167 & $11(5-25)$ & 0.000 \\
\hline Hemoglobin (g/dL) & 177 & $12.6(11.6-13.3)$ & 167 & $12.8(11.7-13.8)$ & 0.201 \\
\hline VAS (mm) & 170 & $60(45-75)$ & 161 & $47(30-67)$ & 0.000 \\
\hline DAS 28-CRP & 172 & $5.3(4.1-6)$ & $>162$ & $4.7(3.5-5.6)$ & 0.000 \\
\hline HAQ & $>152$ & $1.62(1.06-2)$ & 135 & $1.37(0.75-2)$ & 0.027 \\
\hline $\operatorname{PLT}\left(\times 10^{3} / \mathrm{mm}^{3}\right)$ & 177 & $312(255-383)$ & 166 & $304(245-370)$ & 0.567 \\
\hline \multirow[t]{2}{*}{ Creatinine } & 174 & $0.7(0.6-0.8)$ & 167 & $0.7(0.6-0.8)$ & 0.027 \\
\hline & $N$ & $\mathrm{n}(\%)$ & $N$ & $\mathrm{n}(\%)$ & $p^{* *}$ \\
\hline Women & 635 & $481(76 \%)$ & 322 & 277 (86\%) & 0.000 \\
\hline RF presence & 352 & $241(68 \%)$ & 208 & $144(69 \%)$ & 0.850 \\
\hline anti-CCP presence & 179 & $141(77 \%)$ & 168 & $138(72 \%)$ & 0.429 \\
\hline
\end{tabular}

\subsection{KDR Protein Level in Healthy Subjects and Patients with RA. Association with RA Clinical Phenotype}

Because KDR plays a significant role in angiogenesis and inflammation, we decided to correlate the KDR serum levels not only with susceptibility to RA but also with the severity of RA. The KDR serum level was assessed in 272 RA patients and 290 healthy individuals. We observed that KDR serum level was higher in RA patients comparing with healthy subjects $(8018 \mathrm{pg} / \mathrm{mL}$ versus 7381 $\mathrm{pg} / \mathrm{mL}, p=0.002$; Figure 2).

In the next step, we divided our RA patients into two groups: in group I, was RA patients with high disease activity (DAS-28 $\geq 5.0$ ), RF-positive, ACPA-positive, and CVD presence; while group II contained the RA patients with low disease activity and without ACPA, RF, and CVD. The KDR serum level was compared between both these groups (Table 6). We found no association between KDR serum level and RA phenotype. Although, we observed some tendency to differences in KDR serum level between both groups. We observed that the KDR serum level was higher in RA men comparing with RA women $(p=0.093)$. Moreover, RA patients with a number of swollen joints $<3$ as well as a number of tender joints $<7$ had a higher KDR serum level than RA patients from group I (both $p=0.081$ ). 


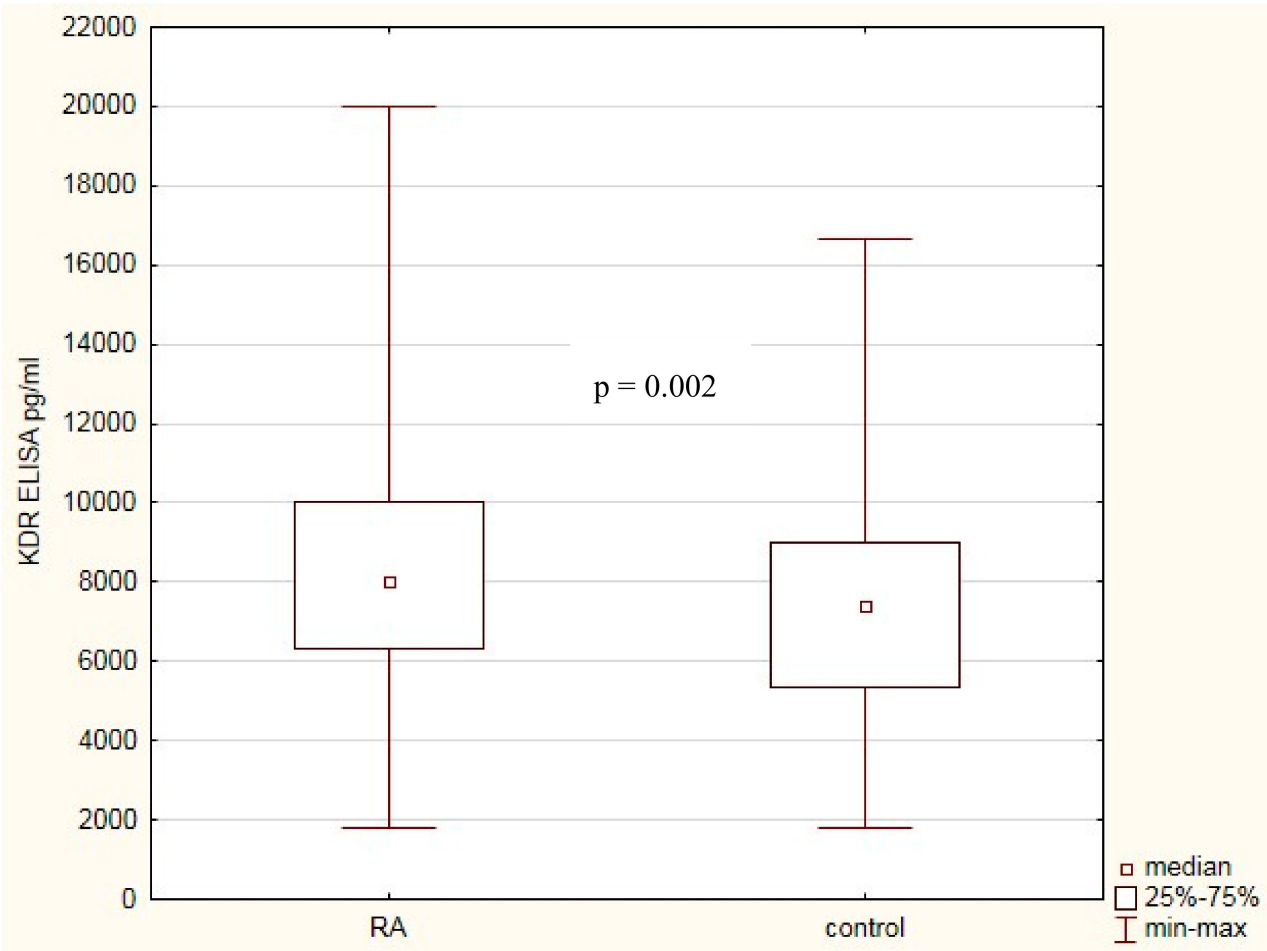

Figure 2. KDR serum concentrations in RA patients and healthy subjects.

Table 6. Correlation of KDR protein concentration of the various clinical parameters (RA).

\begin{tabular}{|c|c|c|c|c|c|c|c|}
\hline \multirow[t]{2}{*}{ Parameter } & \multicolumn{4}{|c|}{$\begin{array}{c}\text { KDR } \\
\text { Protein Level }\end{array}$} & \multicolumn{2}{|c|}{$\begin{array}{c}\text { KDR } \\
\text { Protein Level }\end{array}$} & \multirow[t]{2}{*}{$p$} \\
\hline & $\begin{array}{l}\text { Parameter } \\
\text { Group I }\end{array}$ & $N$ & $\begin{array}{l}\text { Median } \\
\text { (IQR) }\end{array}$ & $\begin{array}{c}\text { Parameter } \\
\text { Group II }\end{array}$ & $N$ & $\begin{array}{l}\text { Median } \\
\text { (IQR) }\end{array}$ & \\
\hline age & age $\geq 56$ & 146 & $\begin{array}{c}8042 \\
(6575-9935)\end{array}$ & age $<56$ & 126 & $\begin{array}{c}7893 \\
(5836-10246)\end{array}$ & 0.337 \\
\hline sex & women & 253 & $\begin{array}{c}7955 \\
(6226-9848)\end{array}$ & men & 19 & $\begin{array}{c}9867 \\
(6575-10910)\end{array}$ & 0.093 \\
\hline RF & $\mathrm{RF}+$ & 169 & $\begin{array}{c}7964 \\
(6042-10032)\end{array}$ & RF - & 97 & $\begin{array}{c}8457 \\
(6595-10246)\end{array}$ & 0.413 \\
\hline anti-CCP & $\mathrm{a}-\mathrm{CCP}+$ & 207 & $\begin{array}{c}8006 \\
(6294-10032)\end{array}$ & a-CCP - & 58 & $\begin{array}{c}8254 \\
(6438-10323)\end{array}$ & 0.586 \\
\hline disease duration & $\geq 10$ & 151 & $\begin{array}{c}8065 \\
(6429-10032)\end{array}$ & $<10$ & 113 & $\begin{array}{c}7825 \\
(6101-10140)\end{array}$ & 0.894 \\
\hline ESR & $\geq 30$ & 124 & $\begin{array}{c}8269 \\
(6434-9966)\end{array}$ & $<30$ & 141 & $\begin{array}{c}7825 \\
(6042-10128)\end{array}$ & 0.420 \\
\hline number of tender joints & $\geq 7$ & 155 & $\begin{array}{c}7415 \\
(5852-9997)\end{array}$ & $<7$ & 107 & $\begin{array}{c}8370 \\
(6892-10360)\end{array}$ & 0.081 \\
\hline number of swollen joints & $\geq 3$ & 141 & $\begin{array}{c}7375 \\
(5836-9997)\end{array}$ & $<3$ & 121 & $\begin{array}{c}8449 \\
(7008-10323)\end{array}$ & 0.081 \\
\hline CRP & $\geq 13$ & 121 & $\begin{array}{c}8006 \\
(6006-9518)\end{array}$ & $<13$ & 143 & $\begin{array}{c}8091 \\
(6556-10450)\end{array}$ & 0.191 \\
\hline DAS-28 & $\geq 5.0$ & 127 & $\begin{array}{c}7791 \\
(5894-9997)\end{array}$ & $<5.0$ & 133 & $\begin{array}{c}8032 \\
(6556-10246)\end{array}$ & 0.508 \\
\hline HAQ & $\geq 1.5$ & 126 & $\begin{array}{c}7722 \\
(5836-10141)\end{array}$ & $<1.5$ & 113 & $\begin{array}{c}7887 \\
(6556-9642)\end{array}$ & 0.789 \\
\hline cardiovascular diseases & $\begin{array}{c}\text { CAD + } \\
\text { (CAD, } \\
\text { HNT, MI) }\end{array}$ & 117 & $\begin{array}{c}7791 \\
(6423-10360)\end{array}$ & CAD - & 145 & $\begin{array}{c}8032 \\
(6303-9848)\end{array}$ & 0.889 \\
\hline
\end{tabular}




\subsection{KDR Genetic Variants with Respect to KDR Protein Levels}

The last step of our analysis was to determine the impact of KDR gene SNPs on KDR protein levels in RA patients and healthy subjects. First, we conducted a comparative analysis between RA patients and controls in relation to KDR rs1870377, rs2071559, and rs2305948 polymorphisms (Table 7). KDR protein levels in RA patients with rs1870377AA, rs2071559CT, and rs2305948GA genotypes were significantly higher compared to controls with the same KDR genotypes ( $p=0.001, p=0.002$, and $p=0.001$, respectively).

Table 7. Variation in KDR expression levels in RA patients and the control group in relation to KDR gene polymorphisms.

\begin{tabular}{|c|c|c|c|c|c|}
\hline \multirow{2}{*}{ Genotype } & \multicolumn{2}{|c|}{ RA Group } & \multicolumn{2}{|c|}{ Control Group } & \multirow{2}{*}{$p$} \\
\hline & $N$ & Median (IQR) & $N$ & Median (IQR) & \\
\hline \multicolumn{6}{|c|}{ KDR $(+1416 \mathrm{~A} / \mathrm{T})$} \\
\hline AA & 127 & $\begin{array}{c}8766 \\
(6802-10495) \\
\end{array}$ & 146 & $\begin{array}{c}7479 \\
(5297-9181) \\
\end{array}$ & 0.001 \\
\hline $\mathrm{AT}$ & 96 & $\begin{array}{c}7611 \\
(6199-9457) \\
\end{array}$ & 97 & $\begin{array}{c}7527 \\
(5341-8963) \\
\end{array}$ & 0.512 \\
\hline $\mathrm{TT}$ & 39 & $\begin{array}{c}7365 \\
(6042-9997)\end{array}$ & 20 & $\begin{array}{c}6997 \\
(5322-9204)\end{array}$ & 0.325 \\
\hline \multicolumn{6}{|c|}{ KDR (+889G/A) } \\
\hline GG & 124 & $\begin{array}{c}7425 \\
(5681-9539)\end{array}$ & 205 & $\begin{array}{c}7384 \\
(5348-8973)\end{array}$ & 0.398 \\
\hline GA & 147 & $\begin{array}{c}8264 \\
(6875-10360)\end{array}$ & 83 & $\begin{array}{c}7371 \\
(5469-8919)\end{array}$ & 0.002 \\
\hline $\mathrm{AA}$ & 1 & - & 1 & - & - \\
\hline \multicolumn{6}{|c|}{$\operatorname{KDR}(-604 \mathrm{~T} / \mathrm{C})$} \\
\hline $\mathrm{TT}$ & 68 & $\begin{array}{c}8269 \\
(6683-10043)\end{array}$ & 17 & $\begin{array}{c}8917 \\
(7416-9312)\end{array}$ & 0.934 \\
\hline $\mathrm{TC}$ & 152 & $\begin{array}{c}8410 \\
(6511-10455)\end{array}$ & 200 & $\begin{array}{c}7336 \\
(5341-8826)\end{array}$ & 0.001 \\
\hline $\mathrm{CC}$ & 51 & $\begin{array}{c}6786 \\
(5282-8568)\end{array}$ & 72 & $\begin{array}{c}6979 \\
(5139-9288)\end{array}$ & 0.900 \\
\hline
\end{tabular}

$\mathrm{N}$-number of patients.

Next, we determined the relationship between KDR protein levels in RA patients according to $K D R$ gene polymorphisms (Figure 3). We found some differences among RA patients in relation to KDR gene SNPs. In RA patients with the KDR rs1870377AA genotype, the KDR serum levels were significantly higher compared with RA patients with KDR rs1870377AT or rs1870377TT genotypes $(p=0.03)$. RA patients with rs2071559CC genotype had the lowest KDR serum levels comparing with RA patients with rs2071559CT or rs2071559TT genotypes $(p=0.009)$. Furthermore, RA patients with rs2305948GA genotype had the highest, and RA patients with rs2305948GG genotype had the lowest KDR serum levels $(p=0.02)$. 

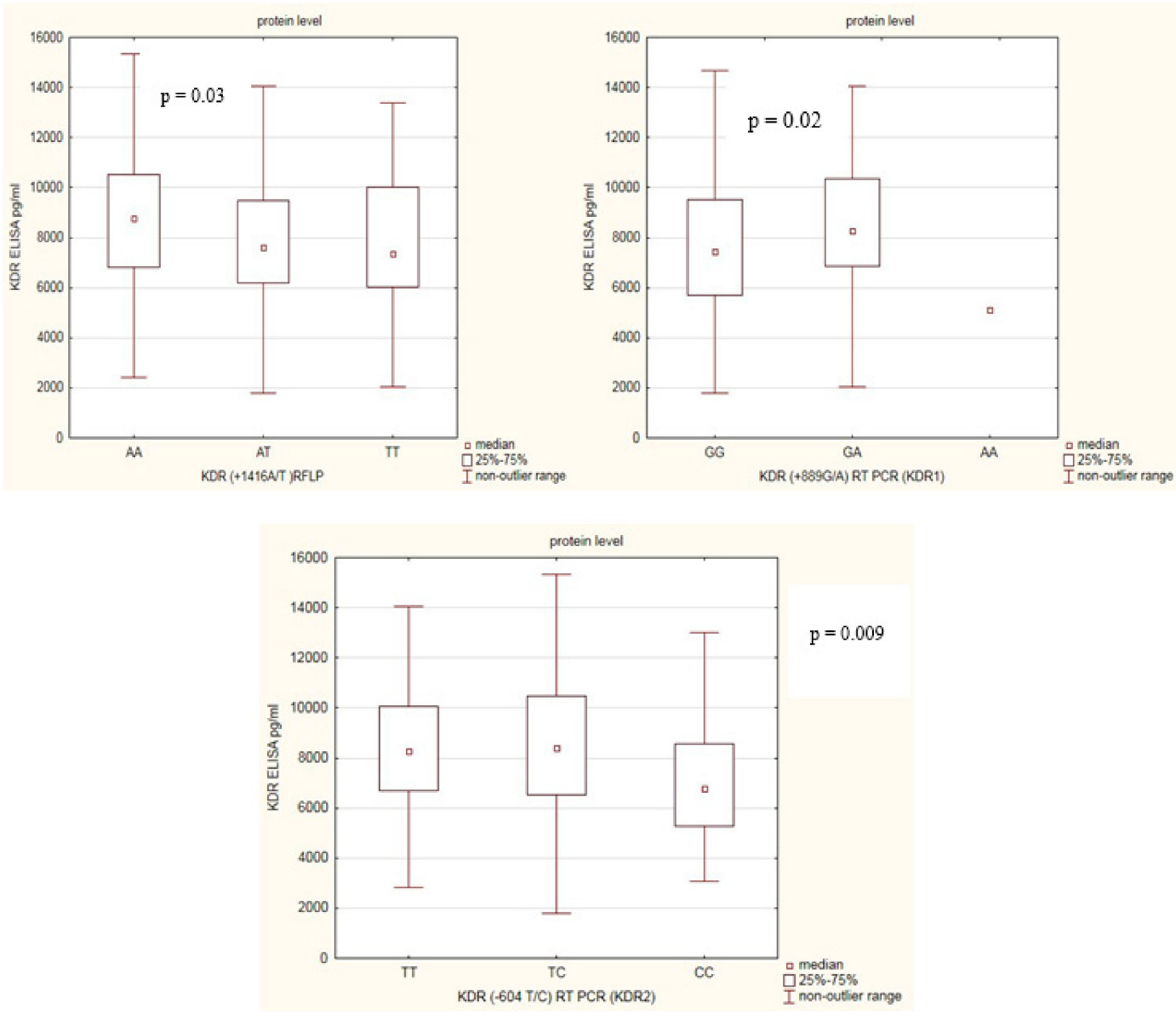

Figure 3. Variation in KDR serum levels in RA patients in relation to KDR genotypes.

\section{Discussion}

We investigated, for the first time to our knowledge, the potential involvement of the KDR (VEGFR2) gene polymorphisms in rheumatoid arthritis susceptibility and severity. In the present study, we observed that the KDR rs1870377TT genotype, rs2305948A allele and rs1870377T/rs2305948A/rs2071559T haplotypes showed significant association with risk of RA. Furthermore, the KDR rs2071559C genetic variant and rs1870377A/+889 G/rs2071559C haplotype may play a protective role in the development of RA in our population. Additionally, in our study, we also found that the KDR rs2305948GG genotype showed a significant positive association with disease severity.

One of the key measures of severity of rheumatoid arthritis is angiogenesis playing a central role in the inflammation and joint damage $[4,5,34,35]$. The best-characterized system regulating the angiogenesis in the rheumatoid joint is VEGF-VEGFRs [12]. In RA patients, KDR expression is upregulated in synovial tissue [3], but during hypoxic conditions, plasma membrane levels of KDR are depleted [36]. Some previous reports have described the KDR mRNA expression levels in RA patients $[11,35]$, but this study is the first study that examined the KDR protein levels in the blood of RA patients. We have shown that KDR protein levels in patients with RA were higher than in healthy subjects, reflecting not only the inflammation but also angiogenesis in RA patients. Binding of VEGF to KDR initiates the activation of the phospholipase C-gamma (PLC- $\gamma$ )/mitogen activated protein kinase (MAPK) pathway and promotion of endothelial cell proliferation $[37,38]$ as well as PLC- $\gamma /$ phosphatidylinositol $3^{\prime}$ kinase (PI3K)/AKT pathway leading to cell migration and vascular permeability [37]. On the other hand, we also observed that the KDR serum levels were higher in RA patients with lower disease activity (group II, Table 6). We can speculate that this situation may be caused by increased hypoxia in the inflamed joints of the RA patients from group I. Increased hypoxia 
through selective activation of anti-angiogenic molecule expression, such as VEGFR1 (FLT-1), acts as a negative regulator for VEGF activity by KDR.

Limited data are available on the effect of polymorphisms of angiogenic factors such as KDR on arthritic pathophysiology, despite angiogenesis playing an important role in the RA pathogenesis. In contrast, some studies have shown that polymorphisms located in the KDR gene are associated with the risk of several human diseases such as chronic myeloid leukemia, breast cancer, glioblastoma, colorectal cancer, cardiovascular disease, or type 2 diabetes [31,39-46]. In rheumatoid arthritis, research focuses more on determining the angiogenic factors' mRNA expression than on the analysis of genetic variants. Determining the genetic predisposition for RA is difficult due to the number of disruptive factors. That is why analysis of genetic variants of factors influencing the susceptibility to or severity of RA is so important; to determine new factors that predispose to RA. In this study, we defined three $K D R$ genetic variations in Polish RA patients and assessed the phenotypic impact of these functional variants. We found that two of these three examined SNPs have a significant effect on RA susceptibility. The KDR rs1870377T variant, located in exon 11, decreased the KDR serum expression levels and, at the same time, increased the risk of RA in our population. In contrast, the KDR rs2071559C variant, located in the 3'-UTR region, also decreased the KDR serum expression levels and may play a protective role in the development of RA in our population. Furthermore, we demonstrated that one of these three studied genetic variants had a strong effect on RA phenotype. The KDR rs2305948GG genotype, located in exon 7, decreased KDR serum expression levels and lead to higher disease activity in our patients. We suggest that the decreased KDR protein expression associated with a regulatory SNP at position rs2071559C appears to be due to a gene transcription mechanism. It is possible that this polymorphism may decrease identification, as well as binding, of VEGF to KDR, which can affect the gene expression and inhibit angiogenesis leading to lower risk of RA in our population. Moreover, in our opinion, the decreased KDR protein expression in RA patients, associated with two functional KDR gene SNPs at position rs1870377T and rs2305948GG, appears to be due to lower affinity of VEGF to KDR, which results in dysfunctional KDR, higher affinity VEGF for FLT-1 or hypoxia-inducible factor (HIF)- $1 \alpha$, intensified angiogenesis, and a higher risk of RA, as well as higher disease activity in our patients. Also, several genetic variants located in the VEGF-A gene have shown associations with rheumatoid arthritis, cancer, coronary artery disease, and chronic obstructive pulmonary disease. The rs1570360, rs699947, rs2010963, rs833070, and rs3025030 VEGF gene polymorphisms were associated with RA [23,47], cancer [48-52], heart disease [53], chronic obstructive pulmonary disease [54,55], or type 2 diabetes [56]. While the VEGF-C gene polymorphisms were not examined in patients with RA, they were examined in patients with cancer and Kawasaki disease. VEGF-C rs7664413, rs2046463, and rs1485766 SNPs have shown association with cancer [57-59], and -634 G/C have shown association with Kawasaki disease [60].

In our study, we observed that not all examined polymorphisms were concordant with HWE; this can be treated as a limitation. Deviations from HWE can be very informative; they could imply a sampling bias, inbreeding, genetic drifting, mistyping of genotypes, differential survival of marker carriers, ethnic differences, sample size, populations stratification or migration, and/or a combination of these reasons. Firstly, we checked for genotype call errors. The genotyping error minimization was achieved by randomLy repeating genotyping on $20 \%$ of selected samples ( $10 \%$ for RA patients, and $10 \%$ for healthy subjects), giving complete conformity of the result. Secondly, our sample size is relatively small; this may lead to genetic drift, which can result in a loss of polymorphism and drive the frequency of one allele to 1.

However, in the case of subjects, withdrawal from HWE, assuming that sources of errors have been eliminated, may indicate a genetic association and a connection of the locus with the disease.

In summary, our results suggested that examined KDR genetic variants may be associated with rheumatoid arthritis either by increased or decreased KDR protein expression levels. In addition, our study has shown that not only hypoxic condition but also gene polymorphisms, may change KDR expression levels and lead to different RA activity. Our findings may help in understanding 
the molecular genetics of angiogenesis as well as inflammation, not only in RA but also in other autoimmune diseases. Our results should be confirmed on larger sample sizes and in different populations. However, this is the first study supplying the evidence on the associations between KDR SNPs, KDR serum levels, and susceptibility to and severity of RA.

\section{Materials and Methods}

\subsection{Study Population}

RA patients included for this study were recruited from the National Institute of Geriatrics, Rheumatology, and Rehabilitation in Warsaw, Poland and from the Pomeranian Medical University in Szczecin, Poland. All patients with RA recruited for this study satisfied the criteria for RA. The inclusion criteria for RA patients were: all (male and female) RA patients who fulfill the 1987 American College of Rheumatology (ACR) or the 2010 EULAR/ACR criteria for RA, aged $\geq 18$ years, and of Polish ethnicity. Exclusion criteria were a history of or current other inflammatory rheumatological or autoimmune disorders; malignancy; significant unstable or uncontrolled acute or chronic disease, which could confound the results of the study and/or current active infection. RA patients who qualified for the study had physical examinations and laboratory tests conducted. Demographic and clinical parameters such as age, gender, disease duration, number of tender and swollen joints, C-reactive protein (CRP), erythrocyte sedimentation ratio (ESR), platelets (PLT), creatinine, presence of rheumatoid factor $(\geq 34 \mathrm{IU} / \mathrm{mL})$, presence of anti-CCP antibodies $(\geq 17 \mathrm{U} / \mathrm{mL})$, disease activity score in 28 joints (DAS-28), visual analogue scale (range 0-100), Health Assessment Questionnaires (range $0-3)$, Larsen score, and extraarticular (ExA) manifestation were collected at the time of the clinical materials sampling.

The control groups were selected from healthy blood bank donor volunteers without a history of autoimmune/inflammatory diseases and cancers. Patients and healthy donors were from the same geographical area, and they had the same ethnicity as well as socioeconomic status.

Informed consent was obtained from all RA patients and healthy individuals included in the study. The study was approved by the Research Ethics Committee of the National Institute of Geriatrics, Rheumatology, and Rehabilitation (of 29 May 2014), and by the Research Ethics Committee of the Pomeranian Medical University. All procedures performed in this study were in accordance with the ethical standards of our Institute and with the 1964 Helsinki declaration and its later amendments or comparable ethical standards.

\subsection{SNP Selection, DNA Extraction and Genetic Analysis}

The KDR genetic markers were selected based on the previous publication and four assumptions: the SNPs with a MAF $<0.05(<5 \%)$ were excluded, the position of SNPs in the KDR gene, possible functional effects, as well as association with other autoimmune diseases. Based on these assumptions for genotyping in our study, we selected three KDR genetic variants: rs2305948, rs2071559, and rs1870377. Genomic DNA was extracted from the blood of RA patients and healthy subjects using the QIAamp DNA Blood Mini Kit (Qiagen, Hilden, Germany) in accordance with the manufacturer's instructions. The TaqMan allelic discrimination assay used to genotype KDR genetic variants were: C_22271999_20 (rs2305948) and C__15869271_10 (rs2071559). The reaction was performed using a Quant Studio 5 detection system (Life Technologies), and reaction conditions were as follows: denaturation at $95^{\circ} \mathrm{C}$ for $10 \mathrm{~min}$, followed by 40 cycles of denaturation at $92^{\circ} \mathrm{C}$ for $15 \mathrm{~s}$, and annealing and extension at $60^{\circ} \mathrm{C}$ for $1 \mathrm{~min}$. SNP genotyping was carried out using the TaqMan ${ }^{\circledR}$ genotyping platform (Life Technologies, Carlsbad, CA, USA).

KDR rs1870377 variant was detected by the polymerase chain reaction (PCR)-restriction fragment length polymorphism (RFLP) method. Reaction mixture contained: $200 \mathrm{ng}$ of genomic DNA, 10 pmol of each primer: forward $5^{\prime}$-TGC TTC CCT CCT GTA TCC TG-3' ${ }^{\prime}$, reverse $5^{\prime}$-C CAT CCT TCC ATT AAA GAG AGA-3', 0.25 mM of each dNTP and 1U HotStar Taq Polymerase (both Qiagen, Hilden, Germany), 
$1 \times$ PCR buffer (containing $1.5 \mu \mathrm{M}$ magnesium chloride, Sigma, MO, USA). Reaction condition was as follows: $95^{\circ} \mathrm{C}$ for $15 \mathrm{~min}, 35$ cycles at $94^{\circ} \mathrm{C}$ for $1 \mathrm{~min}, 49.7^{\circ} \mathrm{C}$ for $1 \mathrm{~min}$ and $72{ }^{\circ} \mathrm{C}$ for $1 \mathrm{~min}$, and a final extension at $72{ }^{\circ} \mathrm{C}$ for $10 \mathrm{~min}$. The PCR product (392 bp) was digested with $1 \mu \mathrm{L}$ of restriction enzyme AluI (Thermo Scientific (Fermentas, Finnzymes, Pierce, Abgene) Waltham, Massachusetts, USA). The results of the digestion were as follows: $392 \mathrm{bp}$ product for allele $\mathrm{T}$ and $173 \mathrm{bp}$ and $219 \mathrm{bp}$ fragments for allele A.

\subsection{Assay for Serum Levels of KDR}

The serum concentration of KDR was determined using a standard sandwich enzyme-linked immunosorbent assay (ELISA) (R\&D System, Abingdon, Oxon, UK) in accordance with the manufacturer's instructions. For each analysis, we used $100 \mu \mathrm{L}$ of serum. All samples were examined in duplicate. The mean value was used for statistical analysis. The minimum detectable dose (MDD) of KDR ranged from 1.0-11.4 pg/mL.

\subsection{Statistical Analysis}

The continuous variables distribution was checked by Shapiro-Wilk test. All continuous variables were not normally distributed; therefore, they are summarized as the median and interquartile range (IQR). The $\chi 2$ test or $\chi 2$ test with Yates' correction (categorical variables) and U Mann-Whitney test (continuous variables) were used to compare the clinical/ serological parameters between groups. The association between SNPs and the risk of RA was estimated by unconditional logistic regression analysis under three genetic models, including codominant, dominant, and recessive models. Odds ratios (ORs) adjusted for sex and age and 95\% confidence intervals (CIs) were calculated. A $p$-value of less than 0.05 was considered significant. All KDR genotype distribution was compared for Hardy-Weinberg Equilibrium (HWE) using the software HardyWeinberg Simulator (available at Institute of Human Genetics, Helmholtz Zentrum München, Germany). The power of the study was calculated using the Genetic Association Study (GAS) Power Calculator (http://csg.sph.umich.edu/abecasis/gas_power calculator/index.htmL). The power was calculated for all examined KDR SNPs, taking into account sample size (641 cases and 340 controls), significance levels (0.05), RA prevalence (0.01), RA allele frequency ( 0.68 for rs1870377, 0.81 for rs2305948, and 0.52 for rs2071559), and genotype relative risk (1.5).

The presence of linkage disequilibrium (LD), as well as a coefficient ( $\mathrm{D}^{\prime}$ and $\mathrm{r} 2$ ) for haplotypes, were carried out using the SHEsis software, available at http://analysis.bio-x.cn [61,62]. We used Bonferroni correction to adjust $p$-values for multiple measures; this correction was used (1) to determine clinical differences between RA patients with and without cardiovascular diseases, and (2) when we correlated KDR gene polymorphisms with the clinical phenotype of RA. Bonferroni-corrected $\alpha$-level of $p<0.003$ was considered statistically significant.

Supplementary Materials: The following are available online at http://www.mdpi.com/2218-273X/9/8/355/s1, Table S1. SNPs information and genotyping results for RA patients and control group. Table S2. Association between genotypes of KDR $+1416 \mathrm{~A} / \mathrm{T}$ and clinical characteristics among RA patients. Table S3. Association between genotypes of KDR $-604 \mathrm{C} / \mathrm{T}$ and clinical characteristics among RA patients.

Author Contributions: A.P.-G. conceived, designed, and performed experiments, analyzed and interpreted data, and wrote the first draft of the manuscript. B.S. and D.M. performed experiments. A.P. contributed to the drafting of the manuscript. K.R.-P. and M.O. were involved in the classification of patients with rheumatoid arthritis, clinical check of patients and treatment control. M.M. performed statistical analysis. All authors read and approved the final version.

Funding: The work was supported by grant S/13 and S/1, National Institute of Geriatrics, Rheumatology and Rehabilitation in Warsaw.

Acknowledgments: The technical assistance of Wieslawa Frankowska and Teresa Golaszewska is gratefully acknowledged. We are also grateful to all of the RA patients and healthy subjects whose cooperation made this study possible.

Conflicts of Interest: The authors declare that they have no conflict of interest. 


\section{References}

1. Zhang, Y.; Qiu, H.; Zhang, H.; Wang, L.; Zhuang, C.; Liu, R. Vascular endothelial growth factor A (VEGFA) polymorphisms in Chinese patients with rheumatoid arthritis. Scand. J. Rheumatol. 2013, 42, 344-348. [CrossRef] [PubMed]

2. Szekanecz, Z.; Koch, A.E. Angiogenesis and its targeting in rheumatoid arthritis. Vasc. Pharmacol. 2009, 90, 249-261. [CrossRef] [PubMed]

3. Kim, H.-R.; Kim, K.-W.; Kim, B.-M.; Cho, M.-L.; Lee, S.-H. The Effect of Vascular Endothelial Growth Factor on Osteoclastogenesis in Rheumatoid Arthritis. PLoS ONE 2015, 10, e0124909. [CrossRef] [PubMed]

4. Paleolog, E.M. Angiogenesis in rheumatoid arthritis. Arthritis Res. 2002, 4, S81-S90. [CrossRef] [PubMed]

5. Azizi, G.; Boghozian, R.; Mirshafiey, A. The potential role of angiogenic factors in rheumatoid arthritis. Int. J. Rheum. Dis. 2014, 17, 369-383. [CrossRef] [PubMed]

6. Szekanecz, Z.; Besenyei, T.; Paragh, G.; Koch, A.E. Angiogenesis in rheumatoid arthritis. Autoimmunity 2009, 42, 563-573. [CrossRef] [PubMed]

7. Tang, X.; Yang, Y.; Yuan, H.; You, J.; Burkatovskaya, M.; Amar, S. Novel transcriptional regulation of VEGF in inflammatory processes. J. Cell. Mol. Med. 2013, 17, 386-397. [CrossRef] [PubMed]

8. Rothenberg, M.E. VEGF obstructs the lungs. Nat. Med. 2004, 10, 1041. [CrossRef]

9. Autiero, M.; Luttun, A.; Tjwa, M.; Carmeliet, P. Placental growth factor and its receptor, vascular endothelial growth factor receptor-1: Novel targets for stimulation of ischemic tissue revascularization and inhibition of angiogenic and inflammatory disorders. J. Thromb. Haemost. 2003, 1, 1356-1370. [CrossRef]

10. Matsumoto, Y.; Tanaka, K.; Hirata, G.; Hanada, M.; Matsuda, S.; Shuto, T.; Iwamoto, Y. Possible Involvement of the Vascular Endothelial Growth Factor-Flt-1-Focal Adhesion Kinase Pathway in Chemotaxis and the Cell Proliferation of Osteoclast Precursor Cells in Arthritic Joints. J. Immunol. 2002, 168, 5824-5831. [CrossRef]

11. Ikeda, M.; Hosoda, Y.; Hirose, S.; Okada, Y.; Ikeda, E. Expression of vascular endothelial growth factor isoforms and their receptors Flt-1, KDR, and neuropilin-1 in synovial tissues of rheumatoid arthritis. J. Pathol. 2000, 191, 426-433. [CrossRef]

12. Shibuya, M.; Claesson-Welsh, L. Signal transduction by VEGF receptors in regulation of angiogenesis and lymphangiogenesis. Exp. Cell Res. 2006, 312, 549-560. [CrossRef] [PubMed]

13. Cao, Y. Positive and Negative Modulation of Angiogenesis by VEGFR1 Ligands. Sci. Signal. $2009,2$. [CrossRef] [PubMed]

14. Sundrani, D.P.; Reddy, U.S.; Joshi, A.A.; Mehendale, S.S.; Chavan-Gautam, P.M.; Hardikar, A.A.; Chandak, G.R.; Joshi, S.R. Differential placental methylation and expression of VEGF, FLT-1 and KDR genes in human term and preterm preeclampsia. Clin. Epigenetics 2013, 5, 6. [CrossRef] [PubMed]

15. Sisto, M.; Lisi, S.; Lofrumento, D.D.; D'Amore, M.; Frassanito, M.A.; Ribatti, D. Sjögren's syndrome pathological neovascularization is regulated by VEGF-A-stimulated TACE-dependent crosstalk between VEGFR2 and NF-кB. Genes Immun. 2012, 13, 411-420. [CrossRef] [PubMed]

16. Hao, Q.; Wang, L.; Tang, H. Vascular endothelial growth factor induces protein kinase D-dependent production of proinflammatory cytokines in endothelial cells. Am. J. Physiol. Physiol. 2009, 296, C821-C827. [CrossRef]

17. Fava, R.A.; Olsan, N.J.; Spancer-Green, G.; Yeo, K.T.; Yeo, T.K.; Berse, B.; Jackman, R.W.; Senger, D.R.; Dvorak, H.F.; Brown, L.F. Vascular permeability factor/endothelial growth factor (VPF/VEGF): Accumulation and expression in human synovial fluids and rheumatoid synovial tissue. J. Exp. Med. 1994, 180, 341-346. [CrossRef] [PubMed]

18. Ballara, S.; Taylor, P.C.; Reusch, P.; Feldmann, M.; Maini, R.N.; Paleolog, E.M.; Marmé, D. Raised serum vascular endothelial growth factor levels are associated with destructive change in inflammatory arthritis. Arthritis Rheum. 2001, 44, 2055-2064. [CrossRef]

19. Clavel, G.; Bessis, N.; Lemeiter, D.; Fardellone, P.; Mejjad, O.; Ménard, J.-F.; Pouplin, S.; Boumier, P.; Vittecoq, O.; Le Loët, X.; et al. Angiogenesis markers (VEGF, soluble receptor of VEGF and angiopoietin-1) in very early arthritis and their association with inflammation and joint destruction. Clin. Immunol. 2007, 124, 158-164. [CrossRef]

20. Lee, S.S.; Joo, Y.S.; Kim, W.U.; Min, D.J.; Min, J.K.; Park, S.H.; Cho, C.S.; Kim, H.Y. Vascular endothelial growth factor levels in the serum and synovial fluid of patients with rheumatoid arthritis. Clin. Exp. Rheumatol. 2001, 19, 321-324. 
21. Sone, H.; Sakauchi, M.; Takahashi, A.; Suzuki, H.; Inoue, N.; Iida, K.; Shimano, H.; Toyoshima, H.; Kawakami, Y.; Okuda, Y.; et al. Elevated levels of vascular endothelial growth factor in the sero of patients with rheumatoid arthritis correlation with disease activity. Life Sci. 2001, 69, 1861-1869. [CrossRef]

22. Carvalho, J.F.; Blank, M.; Shoenfeld, Y. Vascular Endothelial Growth Factor (VEGF) in Autoimmune Diseases. J. Clin. Immunol. 2007, 27, 246-256. [CrossRef]

23. Paradowska-Gorycka, A.; Pawlik, A.; Romanowska-Prochnicka, K.; Haladyj, E.; Malinowski, D.; Stypinska, B.; Manczak, M.; Olesinska, M. Relationship between VEGF Gene Polymorphisms and Serum VEGF Protein Levels in Patients with Rheumatoid Arthritis. PLoS ONE 2016, 11, e0160769. [CrossRef] [PubMed]

24. Bernardes, M.; Durães, C.; Oliveira, A.; Martins, M.J.; Lucas, R.; Costa, L.; Pereira, J.G.; Ramos, I.; Machado, J.C.; Simões-Ventura, F. LRP5 gene polymorphisms and radiographic joint damage in rheumatoid arthritis patients. Osteoporos. Int. 2018, 29, 2355-2368. [CrossRef] [PubMed]

25. Zhi, L.; Yao, S.; Ma, W.; Zhang, W.; Chen, H.; Li, M.; Ma, J. Polymorphisms of RAD51B are associated with rheumatoid arthritis and erosion in rheumatoid arthritis patients. Sci. Rep. 2017, 7, 45876. [CrossRef]

26. Torices, S.; Julia, A.; Muñoz, P.; Varela, I.; Balsa, A.; Marsal, S.; Fernández-Nebro, A.; Blanco, F.; López-Hoyos, M.; Martinez-Taboada, V.; et al. A functional variant of TLR10 modifies the activity of NFkB and may help predict a worse prognosis in patients with rheumatoid arthritis. Arthritis Res. Ther. 2016, 18, 221. [CrossRef] [PubMed]

27. López-Lasanta, M.; Julia, A.; Maymó, J.; Fernández-Gutiérrez, B.; Ureña-Garnica, I.; Blanco, F.J.; Cañete, J.D.; Alperi-López, M.; Olivé, A.; Corominas, H.; et al. Variation at interleukin- 6 receptor gene is associated to joint damage in rheumatoid arthritis. Arthritis Res. Ther. 2015, 17, 242. [CrossRef] [PubMed]

28. Addobbati, C.; da Cruz, H.L.A.; Adelino, J.E.; Melo Tavares Ramos, A.L.; Fragoso, T.S.; Domingues, A.; Branco Pinto Duarte, Â.L.; Oliveira, R.D.R.; Louzada-Júnior, P.; Donadi, E.A.; et al. Polymorphisms and expression of inflammasome genes are associated with the development and severity of rheumatoid arthritis in Brazilian patients. Inflamm. Res. 2018, 67, 255-264. [CrossRef]

29. Paradowska-Gorycka, A.; Sowinska, A.; Pawlik, A.; Malinowski, D.; Stypinska, B.; Haladyj, E.; Romanowska-Prochnicka, K.; Olesinska, M. FLT-1 gene polymorphisms and protein expression profile in rheumatoid arthritis. PLoS ONE 2017, 12, e0172018. [CrossRef]

30. Vernerova, L.; Špoutil, F.; Vlček, M.; Krskova, K.; Penesova, A.; Meskova, M.; Marko, A.; Raslova, K.; Vohnout, B.; Rovenský, J.; et al. A Combination of CD28 (rs1980422) and IRF5 (rs10488631) Polymorphisms Is Associated with Seropositivity in Rheumatoid Arthritis: A Case Control Study. PLoS ONE 2016, 11, e0153316. [CrossRef]

31. Wang, Y.; Zheng, Y.; Zhang, W.; Yu, H.; Lou, K.; Zhang, Y.; Qin, Q.; Zhao, B.; Yang, Y.; Hui, R. Polymorphisms of KDR gene are associated with coronary heart disease. J. Am. Coll. Cardiol. 2007, 50, 760-767. [CrossRef] [PubMed]

32. Park, H.-W.; Shin, E.-S.; Lee, J.; Bahn, J.-W.; Oh, H.-B.; Oh, S.-Y.; Cho, S.-H.; Moon, H.-B.; Min, K.-U. Association between genetic variations of vascular endothelial growth factor receptor 2 and atopy in the Korean population. J. Allergy Clin. Immunol. 2006, 117, 774-779. [CrossRef] [PubMed]

33. Gałecki, P.; Orzechowska, A.; Berent, D.; Talarowska, M.; Bobińska, K.; Gałecka, E.; Lewiński, A.; Maes, M.; Szemraj, J. Vascular endothelial growth factor receptor 2 gene (KDR) polymorphisms and expression levels in depressive disorder. J. Affect. Disord. 2013, 147, 144-149. [CrossRef] [PubMed]

34. Schroeder, M.; Viezens, L.; Fuhrhop, I.; Ruther, W.; Schaefer, C.; Schwarzloh, B.; Algenstaedt, P.; Fink, B.; Hansen-Algenstaedt, N. Angiogenic growth factors in rheumatoid arthritis. Rheumatol. Int. 2013, 33, 523-527. [CrossRef] [PubMed]

35. Sekimoto, T.; Hamada, K.; Oike, Y.; Matsuoka, T.; Matsumoto, M.; Chosa, E.; Suda, T.; Tajima, N.; Yamamura, K. Effect of direcy angiogenesis inhibition in rheumatoid arthritis using a soluble vascular endothelial growth factor receptor 1 chimeric protein. J. Rheumatol. 2002, 29, 240-245. [PubMed]

36. Ulyatt, C.; Walker, J.; Ponnambalam, S. Hypoxia differentially regulates VEGFR1 and VEGFR2 levels and alters intracellular signaling and cell migration in endothelial cells. Biochem. Biophys. Res. Commun. 2011, 404, 774-779. [CrossRef]

37. Clarke, J.M.; I Hurwitz, H. Targeted inhibition of VEGF Receptor-2: An update on Ramucirumab. Expert Opin. Biol. Ther. 2013, 13, 1187-1196. [CrossRef] [PubMed]

38. Fontanella, C.; Ongaro, E.; Bolzonello, S.; Guardascione, M.; Fasola, G.; Aprile, G. Clinical advances in the development of novel VEGFR2 inhibitors. Ann. Transl. Med. 2014, 2, 123. 
39. Liu, D.; Song, J.; Ji, X.; Liu, Z.; Cong, M.; Hu, B. Association of Genetic Polymorphisms on VEGFA and VEGFR2 With Risk of Coronary Heart Disease. Medicine (Baltimore) 2016, 95, e3413. [CrossRef]

40. Zhang, W.; Sun, K.; Zhen, Y.; Wang, D.; Wang, Y.; Chen, J.; Xu, J.; Hu, F.B.; Hui, R. VEGF Receptor-2 Variants Are Associated With Susceptibility to Stroke and Recurrence. Stroke 2009, 40, 2720-2726. [CrossRef]

41. Kim, D.H.; Xu, W.; Kamel-Reid, S.; Liu, X.; Jung, C.W.; Kim, S.; Lipton, J.H. Clinical relevance of vascular endothelial growth factor (VEGFA) and VEGF receptor (VEGFR2) gene polymorphism on the treatment outcome following imatinib therapy. Ann. Oncol. 2010, 21, 1179-1188. [CrossRef] [PubMed]

42. Sjostrom, S.; Wibom, C.; Andersson, U.; Brännström, T.; Broholm, H.; Johansen, C.; Collatz-Laier, H.; Liu, Y.; Bondy, M.; Henriksson, R.; et al. Genetic variations in VEGF and VEGFR2 and glioblastoma outcome. J. Neurooncol. 2010, 104, 523-527. [CrossRef] [PubMed]

43. Beeghly-Fadiel, A.; Shu, X.O.; Lu, W.; Long, J.; Cai, Q.; Xiang, Y.B.; Zheng, Y.; Zhao, Z.; Gu, K.; Gao, Y.T.; et al. Genetic variation in VEGF family genes and breast cancer risk: A report from the Shanghai Breast Cancer Genetics Study. Cancer Epidemiol. Biomarkers Prev. 2011, 20, 33-41. [CrossRef] [PubMed]

44. Schneider, B.P.; Wang, M.; Radovich, M.; Sledge, G.W.; Badve, S.; Thor, A.; Flockhart, D.A.; Hancock, B.; Davidson, N.; Gralow, J.; et al. Association of vascular endothelial growth factor and vascular endothe lial growth factor receptor-2 genetic polymorphisms with outcome in a trial of paclitaxel compared with paclitaxel plus bevacizumab in advanced breast cancer: ECOG 2100. J. Clin. Oncol. 2008, 26, 4672-4678. [CrossRef] [PubMed]

45. Steeghs, N.; Gelderblom, H.; Wessels, J.; Eskens, F.A.; de Bont, N.; Nortier, J.W.; Guchelaar, H.J. Pharmacogenetics of telatinib, a VEGFR-2 and VEGFR-3 tyrosine kinase inhibitor, used in patients with solid tumors. Invest. New Drugs 2011, 29, 137-143. [CrossRef] [PubMed]

46. Kariž, S.; Petrovič, D. Minor association of kinase insert domain-containing receptor gene polymorphism (rs2071559) with myocardial infarction in Caucasians with type 2 diabetes mellitus: Case-control cross-sectional study. Clin. Biochem. 2014, 47, 192-196. [CrossRef] [PubMed]

47. Yi, J.P.; Wu, Y.Z.; Yu, N.; Yu, Z.W.; Xie, F.Y.; Yuan, Q. VEGF Gene Polymorphisms Affect Serum Protein Levels and Alter Disease Activity and Synovial Lesions in Rheumatoid Arthritis. Med. Sci. Monit. 2016, 22, 316-324. [CrossRef]

48. Sullivan, I.; Riera, P.; Andrés, M.; Altés, A.; Majem, M.; Blanco, R.; Capdevila, L.; Barba, A.; Barnadas, A.; Salazar, J. Prognostic effect of VEGF gene variants in metastatic non-small-cell lung cancer patients. Angiogenesis 2019, 22, 433-440. [CrossRef]

49. Song, Y.; Yang, Y.; Liu, L.; Liu, X. Association between five polymorphisms in vascular endothelial growth factor gene and urinary bladder cancer risk: A systematic review and meta-analysis involving 6671 subjects. Gene 2019, 698, 186-197. [CrossRef]

50. Zhang, L.F.; Ren, K.W.; Zuo, L.; Zou, J.G.; Song, N.H.; Mi, Y.Y.; Wang, Z.J.; Zhang, W. VEGF gene rs3025039C/T and rs833052C/A variants are associated with bladder cancer risk in Asian descendants. J. Cell Biochem. 2019, 120, 10402-10412. [CrossRef]

51. Innocenti, F.; Jiang, C.; Sibley, A.B.; Etheridge, A.S.; Hatch, A.J.; Denning, S.; Niedzwiecki, D.; Shterev, I.D.; Lin, J.; Furukawa, Y.; et al. Genetic variation determines VEGF-A plasma levels in cancer patients. Sci. Rep. 2018, 8, 16332. [CrossRef] [PubMed]

52. Gong, M.; Dong, W.; Shi, Z.; Qiu, S.; Yuan, R. Vascular endothelial growth factor gene polymorphisms and the risk of renal cell carcinoma: Evidence from eight case-control studies. Oncotarget 2017, 8, 8447-8458. [CrossRef] [PubMed]

53. Wang, W.; Xu, A.; Xu, H. The roles of vascular endothelial growth factor gene polymorphisms in congenital heart diseases: A meta-analysis. Growth Factors 2018, 36, 232-238. [CrossRef] [PubMed]

54. Baz-Dávila, R.; Espinoza-Jiménez, A.; Rodríguez-Pérez, M.d.C.; Zulueta, J.; Varo, N.; Montejo, Á.; Almeida-González, D.; Aguirre-Jaime, A.; Córdoba-Lanús, E.; Casanova, C. Role of HIF1A, VEGFA and VEGFR2 SNPs in the Susceptibility and Progression of COPD in a Spanish Population. PLoS ONE 2016, 11, e0154998. [CrossRef] [PubMed]

55. Ding, Y.; Niu, H.; Li, Y.; He, P.; Li, Q.; Ouyang, Y.; Li, M.; Hu, Z.; Zhong, Y.; Sun, P.; et al. Polymorphisms in VEGF-A are associated with COPD risk in the Chinese population from Hainan province. J. Genet. 2016, 95, 151-156. [CrossRef] [PubMed] 
56. Sellami, N.; Lamine, L.B.; Turki, A.; Sarray, S.; Jailani, M.; Al-Ansari, A.K.; Ghorbel, M.; Mahjoub, T.; Almawi, W.Y. Association of VEGFA variants with altered VEGF secretion and type 2 diabetes: A case-control study. Cytokine 2018, 106, 29-34. [CrossRef] [PubMed]

57. Tung, M.-C.; Hsieh, M.-J.; Wang, S.-S.; Yang, S.-F.; Chen, S.-S.; Wang, S.-W.; Lee, L.-M.; Lee, W.-J.; Chien, M.-H. Associations of VEGF-C Genetic Polymorphisms with Urothelial Cell Carcinoma Susceptibility Differ between Smokers and Non-Smokers in Taiwan. PLoS ONE 2014, 9, e91147. [CrossRef]

58. Chien, M.H.; Liu, Y.F.; Hsin, C.H.; Lin, C.H.; Shih, C.H.; Yang, S.F.; Cheng, C.W.; Lin, C.W. Impact of VEGF-C gene polymorphisms and environmental factors on oral cancer susceptibility in Taiwan. PLOS ONE 2013, 8, e60283. [CrossRef]

59. Hsieh, M.C.; Hsu, H.T.; Hsiao, P.C.; Yang, S.F.; Yeh, C.B.; Bien, M.Y.; Lin, C.H.; Chien, M.H. Role of VEGF-C gene polymorphisms in susceptibility to hepatocellular carcinoma and its pathological development. J. Clin. Lab. Anal. 2014, 28, 237-244. [CrossRef]

60. Hsueh, K.C.; Lin, Y.J.; Chang, J.S.; Wan, L.; Tsai, Y.H.; Tsai, C.H.; Chen, C.P.; Tsai, F.J. Association of vascular endothelial growth factor C-634 g polymorphism in taiwanese children with Kawasaki disease. Pediatr. Cardiol. 2008, 29, 292-296. [CrossRef]

61. Yong, Y.; He, L. SHEsis, a powerful software platform for analyses of linkage disequilibrium, haplotype construction, and genetic association at polymorphism loci. Cell Res. 2005, 15, 97-98. [CrossRef] [PubMed]

62. Li, Z.; Zhang, Z.; He, Z.; Tang, W.; Li, T.; Zeng, Z.; He, L.; Shi, Y. A partition-ligation-combination-subdivision EM algorithm for haplotype inference with multiallelic markers: Update of the SHEsis (http://analysis.bio-X. cn). Cell Res. 2009, 19, 519-523. [CrossRef] [PubMed]

(C) 2019 by the authors. Licensee MDPI, Basel, Switzerland. This article is an open access article distributed under the terms and conditions of the Creative Commons Attribution (CC BY) license (http://creativecommons.org/licenses/by/4.0/). 